\title{
KOMPARASI MODEL PEMBELAJARAN DISCOVERY LEARNING DAN PROBLEM SOLVING DITINJAU DARI HASIL BELAJAR TEMATIK KELAS 4 SEKOLAH DASAR
}

\author{
Miftah Nugroho ${ }^{1}$, Mawardi $^{2}$, Suhandi Astuti $^{3}$ \\ ${ }^{1,2,3}$ Pendidikan Guru Sekolah Dasar, Universitas Kristen Satya Wacana, Salatiga \\ e-mail: 292014157@ student.uksw.edu'1, mawardi@staff.uksw.edu ${ }^{2}$, \\ $\underline{\text { Suhandi.astuti70@gmail.com }}{ }^{3}$
}

\begin{abstract}
ABSTRAK
Latar belakang penelitian ini adalah adanya keragu-raguan peneliti terhadap keefektifan antara model pembelajaran Discovery Learning dengan model pembelajaran Problem Solving. Jenis penelitian ini menggunakan eksperimen semu dengan menggunakan desain nonequivalent control group design. Pengumpulan data mengunakan teknik tes yaitu pretes dan postes. Sample penelitan siswa kelas 4 SDN Musuk 01, kelas 4 SDN Musuk 02, dan kelas 4 SDN Kembangsari 01 berjumlah 81 siswa. Tekhikanalisis data menggunakanuji ANCOVA. Hasil penelitian menemukan bahwa F hitung sebesar 36,348 dengan taraf signifikansi hitung 0,000 . Oleh karena $0,000<\alpha=0,050$, maka dampak variabel independen secara simultan terhadap variabel dependen signifikan. Artinya model pembelajaran Discovery Learning dan pretest secara simultan memiliki dampak yang berbeda secara signifikan terhadap hasil belajar siswa, dibandingkan dengan model pembelajaran Problem Solving. Dapat disimpulkan bahwa hasil signifikansi sebesar 0,00 lebih kecil dari $\alpha=0,05$ maka $\mathrm{H}_{0}$ ditolak dan $\mathrm{H}_{\mathrm{a}}$ diterima, artinya hasil belajar menggunakan model Discovery Learning lebih unggul secara signifikandalam pembelajaran dan meningkatkan hasil belajar siswa.
\end{abstract}

Kata kunci: Model Pembelajaran Discovery Learning, Problem Solving, Hasil Belajar.

The background of this research is the doubt of researchers on the effectiveness between Discovery Learning learning models and Problem Solving learning models. This type of research uses quasiexperimental using nonequivalent control group design. Data collection uses test techniques namely pretest and posttest. Sample research of 4th grade students of SDN Musuk 01, grade 4 SDN Musuk 02, and grade 4 SDN Kembangsari 01 totaled 81 students. Analyze data using ANCOVA test. The results of the study found that $\mathrm{F}$ calculated was 36.334 with a significance level of 0.000 . Because $0,000<\alpha=0,050$, the impact of independent variables simultaneously on the dependent variable is significant. This means that the Discovery Learning and pretest learning models simultaneously have a significantly different impact on student learning outcomes, compared to the Problem Solving learning model. It can be concluded that the significance of 0.00 is smaller than $\alpha=0.05, \mathrm{H} 0$ is rejected and $\mathrm{Ha}$ is accepted, meaning that the learning outcomes using the Discovery Learning model are superior in terms of learning and improving student learning outcomes.

Keywords: Discovery Learning, Problem Solving, Learning Outcomes 


\section{PENDAHULUAN}

Permendikbud RI nomor 20 tahun 2016 tentang Kompetensi Inti dan Kompetensi Dasar Pelajaran Kurikulum 2013 pada pendidikan Dasar dan Menengah menyatakan bahwa pelaksanaan belajar pada Sekolah Dasar/Madrasah Ibtidaiyah (SD/MI) dilakukan dengan pendekatan pembelajaran tematik terpadu.Trianto (2011: 147) berpendapat bahwa istilah pembelajaran tematik pada dasarnya dalah model pembelajaran terpadu yang menggunakan tema untuk mengaitkan beberapa mata pelajaran sehingga dapat memberikan pengalaman bermakna kepada siswa.Rusman (2011: 254) berpendapat pembelajaran tematik merupakan salah satu model dalam pembelajaran terpadu yang merupakan suatu sistem pembelajaran yang memungkinkan siswa, baik secara individual maupun kelompok, aktif menggali dan menemukan konsep serta prinsip-prinsip keilmuan secara holistik, bermakna, dan autentik.Pembelajaran tematik dimaknai sebagai pembelajaran yang dirancang dan dikemas berdasarkan tema-tema tertentu dan dalam pembahasannya tema-tema ditinjau dari berbagai mata pelajaran dalam setiap pembelajaran (Mawardi\&Rini, 2015:15). Berdasarkan pendapat diatas dapat disimpulkan bahwa pembelajaran tematik merupakan pembelajaran yang memuat beberapa muatan pelajaran yang dirangkum menjadi subtema-subtema yang terapat dalam satu tema. Menurut Mawardi \& Desty Lusia Sari (2015: 82) sebagai seorang guru tidak hanya dituntut untuk memilikipengetahuan dan keterampilan saat melakukan kegiatan belajar mengajar di dalam kelas, tetapi juga harus memiliki kreatifitas. Diantaranya dalam pemilihan model pembelajaran yang sesuai. Model pembelajaran ialah suatu pola yang digunakan untuk penyusunan kurikulum, mengatur materi dan memberi petunjuk kepada guru di kelas (Agus Suprijono, 2009: 46).

Dari sekian banyak model pembelajaran yang ada, salahsatu model pembelajaran yang inovatif adalah model pembelajaran Discovery Learning. Discovery Learningadalah teori belajar yang didefinisikan sebagai proses pembelajaran yang terjadi bila pelajar tidak disajikan dengan pelajaran dalam bentuk finalnya, tetapi diharapkan mengorganisasi sendiri (Depdiknas, 2014). Model Discovery Learning adalah memahami konsep, arti, dan hubungan, melalui proses intuitif untuk akhirnya sampai kepada suatu kesimpulan. Menurut Pardomuan (2013: 17) model pembelajaran Discovery Learning memiliki beberapa langkah-langkah, di antaranya: stimulation (pemberi rangsangan), problem statement (identifikasi masalah), data collecting (pengumpulan data), data processing (pengolahan data), verivication (pembuktian) dan generalization (menarik kesimpulan).Selain model pembelajaran Discovery Learningadalah model pembelajaran Problem Solving. Menurut Djamarah \& Zain (2010: 91-92) mengatakan bahwa modelProblem Solving (pemecahan masalah) bukan hanya sekedar metode mengajar tetapi juga merupakan suatu model berpikir, sebab dalam Problem Solving dapat menggunakan metode-metode lainnya yang dimulai dengan mencari data sampai dengan menarik kesimpulan.Langkah-langkah dalam metode pembelajaran Problem Solving menurut Pepkin (2004) "terdiri dari: klasifikasi masalah, pengungkapan pendapat, evaluasi dan pemilihan, dan implementasi." Langkah pertama, guru memberikan suatu permasalahan yang berkaitan dengan materi pelajaran kepada siswa. Langkah kedua, siswa diberikan keleluasan memberikan pendapat tentang permasalahan tersebut. Langkah ketiga, siswa menganalisis masalah dan menetapkan solusi pemecahannya yang tepat. Langkah keempat, siswa menyelesaikan masalah tersebut dengan solusi yang dipilih dan memberikan alasannya.Melalui metode pembelajaran ini siswa belajar memecahkan masalah untuk mendapatkan pemahaman sendiri, sehingga siswa belajar melalui pengalaman. Pengalaman belajar dengan metode Problem Solving membantu siswa mengembangkan kemampuan berpikir kritisnya. Kedua model pembelajaran tersebut sama-sama dapat diterapkan guru dan menjadi model pembelajaran yang cukup inovatif. Oleh karena itu peneliti ingin melihat perbedaan penerapan model pembelajaran Discovery Learning dan Problem Solving.

I Made Putrayasa, H. Syahruddin, I Gede Margunayasa (2013). Melakukan penelitian tentang Pengaruh Model Pembelajaran Discovery Learning dan Minat Belajar Terhadap Hasil Belajar IPA Siswa. Penelitian menunjukkan bahwa model pembelajaran Discovery Learning dan minat 
belajar berpengaruh terhadap hasil belajar IPA siswa.

Ina Azariya Yupita, Waspodo Tjipto S. Melakukan penelitian tentang Penerapan Model Pembelajaran Discovery Learning untuk Meningkatkan Hasil Belajar IPS di Sekolah Dasar. Penelitian menunjukkan penerapan model pembelajaran Discovery Learning yang dilaksanakan dalam pembelajaran IPS dapat meningkatkan aktivitas guru, aktivitas siswa, dan hasil belajar siswa kelas IV SDN Surabaya dilihat dari hasil yang cukuppadasiklus I, siklus II dan siklus III menunjukkan hasil yang sangat baik dengan ketuntasan belajar Klasikal siklus I mencapai63,89\%, siklus II KetuntasanBelajarKlasikalmencapai77,77\%. Dan pada siklus III Ketuntasan Belajar Klasikal mencapai 94,44\%.

Meiria Sylvi Astuti, melakukan penelitian tentang Peningkatan Keterampilan Bertanya dan Hasil Belajar Siswa Kelas 2 SDN Slungkep 03 Menggunakan Model Discovery Learning. Penelitian menunjukkan penerapan model Discovery Learningyang cukup pada siklus I dan pada siklus II menunjukkan hasil yang sangat baik dengan ketuntasan belajar Klasikal siklus I sebesar $46,67 \%$, dan siklus II sebesar 80,00\%. Ketuntasan hasil belajar siswa tersebut mampu mencapai kategori tinggi rata-rata sebesar $18,19 \%-33,33 \%$.

Berdasarkan uraian di atas, model pembelajaran Discovery Learning dan Problem Solving mempunyai persamaan dapat meningkatkan hasil belajar siswa. Discovery Learning menekankan pada penemuan untuk menemukan kosep dari materi yang akan dipelajari dan keterampilan, Problem Solving menekankan pemecahan masalah secara individu dalam pembelajarannya dan kognitif.

\section{METODE PENELITIAN}

Jenis penelitian ini adalah Penelitian Kualitatif yaitu yang berupa Penelitian Quasi Eksperimental Research atau eksperimen semu. Menurut Sugiyono (2015: 114) eksperimen semu adalah bentuk pengembangan dari eksperimen murni yang sulit untuk dilaksanakan, penelitian eksperimen semu ini dilakukan karena faktanya sulit mendapatkan kelompok kontrol yang digunakan untuk penelitian-penelitian. Penelitian dilakukan menggunakan dua kelompok yaitu kelompok eksperimen 1 dan kelompok eksperimen 2. Kedua kelompok tersebut tidak dipilih secara random atau acak, seperti yang telah dijelaskan sebelumnya, tetapi memang sebuah kelompok yang sudah terbentuk sebelumnya.

Dalam penelitian ini menggunakan desain Nonequivalent Control Group Design. Dalam penelitian ini membandingkan dua kelompok, yaitu kelompok eksperimen dan kontrol. Akan tetapi kelompok eksperimen atau kelompok kontrol ini tidak dipilih secara random (Sugiyono, 2015: 116). Sebelum Treatment dilakukan, subjek diberi pretest atau pengukur awal untuk mengetahui perbedaan keadaan awalan atara kelompok eksperimen 1 dan kelompok eksperimen 2.

Hasil pengukuran awal dikatakan baik jika tidak ada pebedaan secara signifikan antara kedua kelompok tersebut. Setelah diberikan pengukuran awal kemudian kedua kelompok eksperimen diberikan treatment yaitu pembelajaran Tematik dengan model pembelajaran Discovery Learning dan Problem Solving .setelah proses pembelajaran selesai, kemudian diadakan posttest atau pengukuran akhir untuk mengetahui apakah ada perbedaan yang signifikan antara model pembelajaran Discovery Learningdengan model pembelajaran Problem Solving. Adapun desain penelitian Nonequivalent Control Group Design dapat digambarkan dengan tabel sebagai berikut.

Tabel 1. Non equivalent Control Grou Design

\begin{tabular}{llll}
\hline Kelompok & Pretest & Variabel Bebas & Posttest \\
\hline Eksperimen 1 & $\mathrm{O}_{1}$ & $\mathrm{X}_{1}$ & $\mathrm{O}_{2}$ \\
\hline Eksperimen 2 & $\mathrm{O}_{3}$ & $\mathrm{X}_{2}$ & $\mathrm{O}_{4}$ \\
\hline
\end{tabular}

Dari gambar 1.1 diatas terdapat empat kelompok data dalam desain penelitian yaitu grub eksperimen 1 dan eksperimen 2, data pretest kelompok eksperimen $1 \quad\left(\mathrm{O}_{1}\right)$ dan kelompok eksperimen $2\left(\mathrm{O}_{3}\right)$, data posttest kelompok eksperimen $1\left(\mathrm{O}_{2}\right)$ dan kelompok ekperimen $2\left(\mathrm{O}_{4}\right)$. Secara rinci keterangan dari 
desain penelitian tersebut adalah sebagai berikut.

$\mathrm{X}_{1}$ :perlakuan 1 (pembelajaran menggunakan model Discovery Learning)

$\mathrm{X}_{2}$ :perlakuan 2 (pembelajaran menggunakan model Problem Solving)

Penelitian dilakukan di SD Gugus Merbabu yang terletak diwilayah Kecamatan Musuk, Kabupaten Boyolali, Provinsi Jawa Tengah. Adapun Gugus Merbabu terletak di daerah kaki Gunung Merapi sebelah timur dengan mayoritas peduduknya bermata pencaharian petani. Terdapat $8 \mathrm{SD}$ dalam satu gugus, namun peneliti tidak meggunakan semua SD untuk dijadikan sebagai objek penelitian. Peneliti hanya mengambil beberapa SD yang dapat mewakili semua SD di Gugus Merbabu. SD yang digunakan peneliti sebagai objek penelitian terdiri atas SD Negeri Musuk 02 sebagai SD inti, kemudian SD Negeri Musuk 01 sebagai SD imbas dekat, dan SD negeri Kembangsari 01 sebagai SD imbas jauh. Pertibangan memilih sekolah ini untuk penelitian berdasarkan kemudahan akses bagi peneliti untuk mengadakan penelitian.

Teknik pengambilan sampel dalam penelitian ini menggunakan teknik Cluster Sampling (area sampling). Cluster Sampling adalah teknik pengambilan sampel berdasarkan daerah populasi yang ditetapkan (Sugiyono, 2015: 121). Teknik sampling daerah digunakan untuk menentukan sampel bila objek yang akan diteliti atau sumber data sangat luas, jadi seleksi anggota sampel dilakukan dalam kelompok dan bukan seleksi anggota sampel secara individu.

Teknik pengambilan sampel tersebut dilakukan dengan cara memilih salahsatu SD sebagai perwakilan dari beberapa status yang berbeda, dimana perwakilan penelitian ini SD Negeri Musuk 01 mewakili SD imbas dekat, SD Negeri Kembangsari 01 imbas jauh dan SD NegeriMusuk 02 sebagai SD inti. Dalam pengambilan sampel ini juga berdasarkan pada pertimbangan bahwa setiap cluster mempunyai karakteristik siswa dan lingkungan belajar yang hampir sama.

\section{HASIL DAN PEMBAHASAN}

Hasil

Deskripsi Data Kelompok Eksperimen

Seperti telah dikemukakan pada bagian metode penelitian, bahwa yang dijadikan kelas eksperimen adalah siswa kelas IV SD pada tabel 1.1 dibawah ini merangkum data empirik tingkat hasil belajar siswa setelah diterapkan dua model pembelajaran yaitu model discovery learnng yang telah diklasifikasikan berdasarkan ketegori tuntas dan belum tuntas. Deskriptif statistik dengan ukuran skor minimum, maksimum, rentang skor, mean, standar deviasi.

Tabel 2. Descriptive Statistics Skor Pretest dan Posttest Kelompok Eksperimen

\begin{tabular}{llllll}
\hline & N & Min & Max & Mean & Std. Devination \\
& & & & & \\
\hline Pretest_DL & 41 & 20 & 70 & 49.02 & 12.997 \\
\hline Posttets_DL & 41 & 43 & 93 & 73.34 & 12.09258 \\
\hline Valid & 41 & & & & \\
N(listwise) & & & & & \\
\hline
\end{tabular}


Tabel 3. Distribusi Frekuensi Hasil Belajar Nilai Pretest dan Postest Kelompok Eksperimen

\begin{tabular}{|c|c|c|}
\hline \multirow{2}{*}{$\begin{array}{cc}\text { No } & \text { Kelas } \\
& \text { Interval } \\
& \text { Pretest }\end{array}$} & \multicolumn{2}{|c|}{ Nilai Pretest } \\
\hline & Frekuensi & Presentase \\
\hline $120-27$ & 2 & $4,8 \%$ \\
\hline $28-35$ & 4 & $9,7 \%$ \\
\hline $36-43$ & 9 & $21,9 \%$ \\
\hline $44-51$ & 7 & $17,07 \%$ \\
\hline $5 \quad 52-59$ & 4 & $9,7 \%$ \\
\hline$\geq 60$ & 15 & $36,5 \%$ \\
\hline Jumlah & 41 & $100 \%$ \\
\hline \multirow{2}{*}{$\begin{array}{c}\text { Kelas Interval } \\
\text { Posttest }\end{array}$} & Nilai Posttest & \\
\hline & Frekensi & Presentase \\
\hline $43-50$ & 2 & $4,8 \%$ \\
\hline $51-58$ & 3 & $7,3 \%$ \\
\hline $59-67$ & 8 & $19,5 \%$ \\
\hline $68-75$ & 9 & $21,9 \%$ \\
\hline $76-84$ & 10 & $24,3 \%$ \\
\hline \multirow[t]{2}{*}{$\geq 85$} & 9 & $21,9 \%$ \\
\hline & 41 & $100 \%$ \\
\hline
\end{tabular}

Berdasarkan tabel 2 diatas dapat diketahui bahwa sebelum mendapat perlakuan menggunakan model Discovery Learning nilai rata-rata pretest kelompok eksperimen 1 sebesar 49,02 dengan standar deviasi sebesar 12,997. Sedangkan setelah kelompok eksperimen 1 diberi perlakuan dengan perlakuan Discovery Learning dalam pembelajaran nilai rata-rata posttest meningkat menjadi 73,34 dengan standar deviasi 12,09258 .

Berdasarkan perhitungan nilai Pretest dan Postest dengan menggunakan rumus diatas, maka daftar distribusi frekuensi hasil belajar nilai Pretest dan Postest kelompok eksperimen 1 dapat dilihat pada tabel 1.2 berikut:

Berdasarkan tabel 2 di atas dapat diketahui bahwa distribusi frekuensi nilai pretest kelompok eksperimen 1 diantaranya terdapat 1 siswa yang mendapatkan skor 24-31 dengan persentase 3\%, 6 siswa yang mendapatkan skor 32-39 dengan persentase
18\%, 9 siswa mendapatkan skor 40-47 dengan persentase $26 \%, 8$ siswa mendapatkan skor 48 55 dengan persentase 23\%, 4 siswa mendapatkan skor 56-63 dengan persentase $12 \%$ dan 6 siswa dengan persentase $18 \%$ mendapatkan nilai $\geq 64$.

Lebih lanjut distribusi frekuensi pada nilai posttest kelompok eksperimen 1 diantaranya terdapat 2 siswa yang mendapatkan skor 44-51 dengan persentase 5,9\%, 3 siswa mendapatkan skor 52-59 dengan persentase $8,8 \%, 1$ siswa mendapatkan skor 60 67 dengan persentase 2,9\%, 9 siswa mendapatkan skor 68-75 dengan persentase $26,5 \%, 10$ siswa mendapatkan skor 76-83 dengan persentase $29,4 \%$ dan 9 siswa mendapatkan skor $\geq 84$ dengan persentase $26,5 \%$. Secara lebih jelas tabel distribusi frekuensi hasil belajar Tematik siswa kelas 4 kelompok eksperimen 1 menggunakan model Discovery Learningdisajikan dalam bentuk grafik sebagai berikut. 


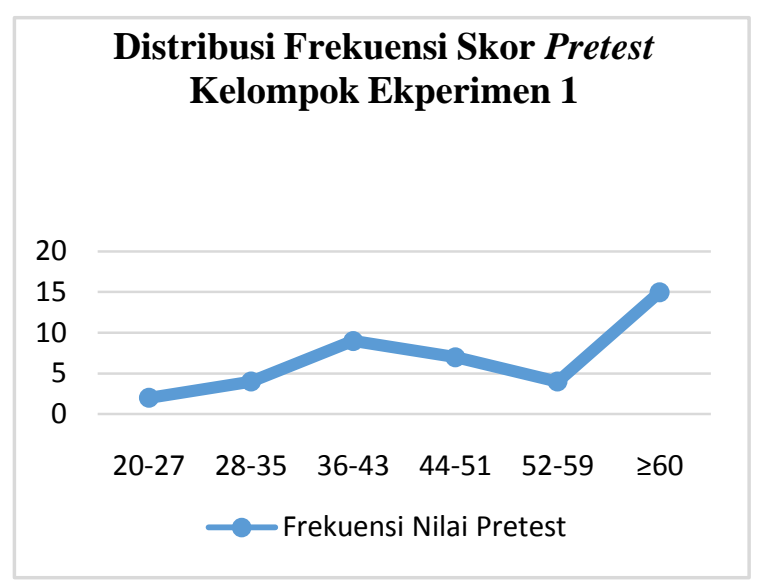

Gambar 1. Grafik Distribusi Frekuensi Skor Pretest Kelompok Eksperimen 1 Menggunakan Model Discovery Learning

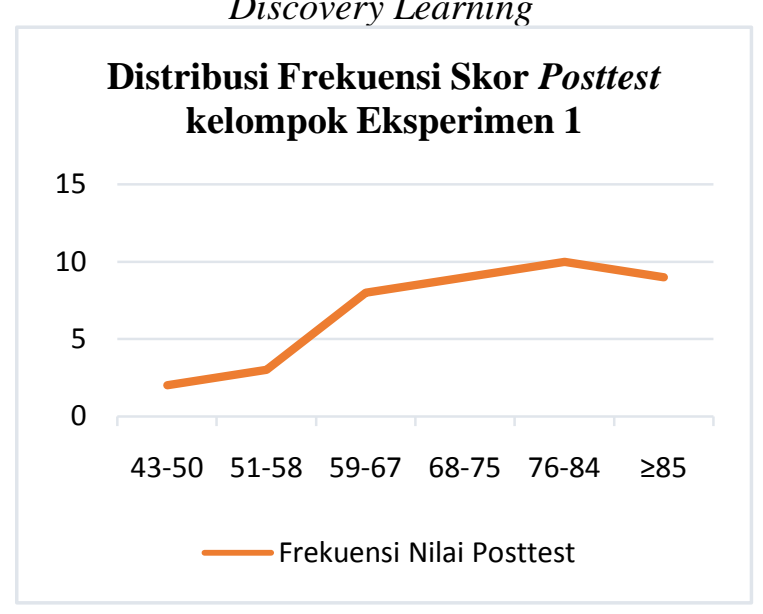

Gambar 2.Grafik Distribusi Frekuensi Skor Posttest Kelompok Eksperimen 1 Menggunakan Model Dicovery Learning

Hasil Implementasi Pembelajaran Tematik Menggunakan Model Problem Solving Sebagai Kelompok Eksperimen 2. Pembelajaran Tematikdengan menggunakan model Problem Solving pada hasil implementasi kelompok ekperimen 2 yang terdiri atas siswa kelas IVB SD Negeri Musuk 02 sebagai SD inti dan SD Negeri Kembangsari 01. Tingkat Hasil Belajar Tematik Siswa kelas IV SD Menggunakan Model Problem Solving Pada kelompok Eksperimen 2 Tingkat hasil belajar siswa kelas IV SD pada kelompok eksperimen 2dengan menerapkan model Problem Solving dipaparkan dalam statistik deskriptif. Pemaparan statistic deskriptif berupa pretest dan posttestdisajikan dalam bentuk tabel yang terdiri dari rata-rata nilai (mean), skor tertinggi ( $\max$ ), skor terendah ( $\min )$, standar deviasi, distribusi frekuensi dan penyajiannya dalam bentuk grafik. Statistik deskriptif skor pretest dan posttest kelompok eksperimen 2 disajikan pada tabel1.3 dibawah ini yang diolah menggunakan aplikasi SPSS for windows versi 16. 
Tabel 4. Descriptive Statistic Nilai Pretest dan Posttest Kelompok Eksperimen 2

\begin{tabular}{llccrl}
\hline & N & Min & Max & Mean $\begin{array}{l}\text { Std. } \\
\text { Devination }\end{array}$ \\
\hline Pretest_PS & 40 & 20 & 70 & 49.83 & 11.899 \\
\hline Posttets_PS & 41 & 50 & 93 & 71.75 & 11.79996 \\
\hline Valid N(listwise) & 40 & & & & \\
\hline
\end{tabular}

Berdasarkan tabel 4 di atas dapat dilihat bahwa sebelum proses pembelajaran mendapatkan perlakuan menggunakan model Problem Solving nilai rata-rata Pretest kelompok Eksperimen 2 sebesar 49,83 dengan standar deviasi 11,899. Sedangkan setelah kelompok Ekperimen2 diberi perlakuan menggunakan model Problem Solvingnilai rata-rata Posttest kelompok eksperimen 2 meningkat menjadi 71,7561 dengan standar deviasi 11.79996. Tabel di atas juga menunjukkan bahwa skor tertinggi sebelum diberi perlakuan adalah 70 dan skor terendah 20. Namun setelah kelompok kontrol diberi perlakuan berupa penerapan model Problem Solvingskor tertinggi yang berhasil diperoleh sebesar 93 dan skor terendah 50. Jumlah siswa yang mengikuti Pretest dan Posttest kelompok eksperimen 2 ini adalah 41 anak.

Berdasarkan perhitungan nilai Pretest dan Posttest diatas, maka daftar distribusi frekuensi hasil belajar nilai Pretest dan Posttest kelompok eksperimen 2 dapat dilihat pada tabel 1.4 sebagai berikut.

Tabel 5. Distribusi Frekuensi Nilai Pretest dan Posttest Kelompok Eksperimen2

\begin{tabular}{cccc}
\hline No & Kelas & \multicolumn{2}{c}{ Nilai Pretest } \\
\cline { 3 - 4 } & Interval & Frekuensi & Persentase \\
& Pretest & & $4,7 \%$ \\
\hline 1 & $20-27$ & 2 & $10 \%$ \\
\hline 2 & $28-35$ & 4 & $10 \%$ \\
\hline 3 & $36-43$ & 4 & $27,5 \%$ \\
\hline 4 & $43-50$ & 11 & $22,5 \%$ \\
\hline 5 & $51-59$ & 9 & $25 \%$ \\
\hline 6 & $\geq 60$ & 10 & $100 \%$ \\
\hline Jumlah & 40 & \\
\hline & Kelas & Nilai Posttest & Persentase \\
\cline { 2 - 4 } Interval & Frekuensi & $4,7 \%$ \\
\hline Posttest & & $4,7 \%$ \\
\hline $50-56$ & 2 & $4,7 \%$ \\
\hline & 2 & $4,7 \%$ \\
\hline $57-63$ & 2 & $12,5 \%$ \\
\hline $64-50$ & 2 & $67,5 \%$ \\
\hline $51-57$ & 5 & $100 \%$ \\
\hline $58-64$ & 27 &
\end{tabular}

Berdasarkan tabel 5 dapat diketahui bahwa pada skor Pretest kelompok eksperimen 2 terdapat 2 siswa yang mendapatkan skor antara 20-27 dengan persentase $4,7 \%, 4$ anak mendapatkan skor antara 28-35 dengan persentase 10\%, 4 siswa mendapatkan skor 36-43 dengan persentase $10 \%, 11$ siswa mendapatkan skor 43-50 dengan persentase $27,5 \%, 9$ siswa mendapatkan skor antara 51-59 dengan persentase $22,5 \%$ dan 10 anak mendapatkan skor $\geq 60$ dengan persentase $25 \%$.

Lebih lanjut skor posttest yang didapat pada kelompok eksperimen 2 yaitu 2 siswa mendapatkan skor 50-56 dengan persentase 4,7\%, 2 siswa mendapatkan skor 57-63 dengan persentase 4,7\%, 2 siswa mendapatkan skor 64-50 dengan persentase 4,7\%, 2 siswa 
mendapatkan skor 51-57 dengan persentase 4,7\%, 5 siswa mendapatkan skor 58-64 dengan persentase $12,5 \%$ dan 27 anak mendapatkan skor $\geq 65$ dengan persentase $67,5 \%$
Secara lebih jelas tabel istribusi frekuensi hasil belajar Tematik siswa kelas IV kelompok eksperimen 2 menggunakan model ProblemSolving disajikan dalam bentuk sebagai berikut.

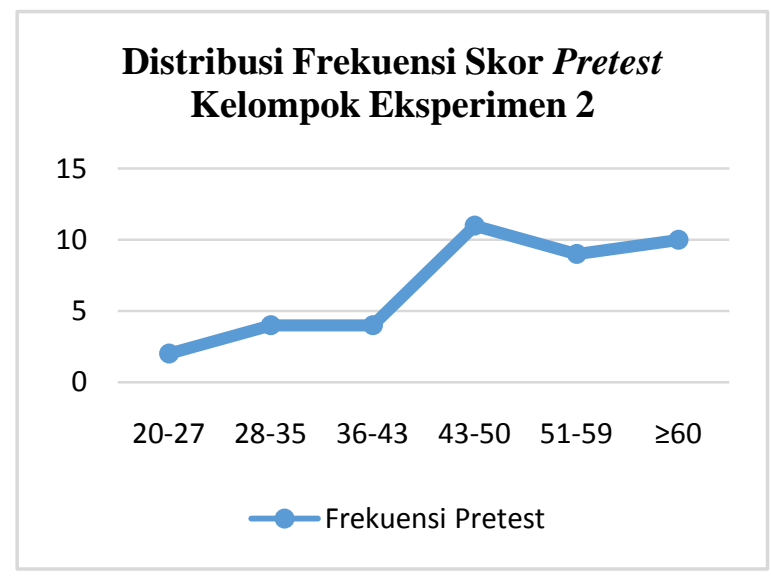

Gambar 3.

Grafik Distribusi Frekuensi Skor Pretest Kelompok Eksperimen 2

Menggunakan Model Problem Solving

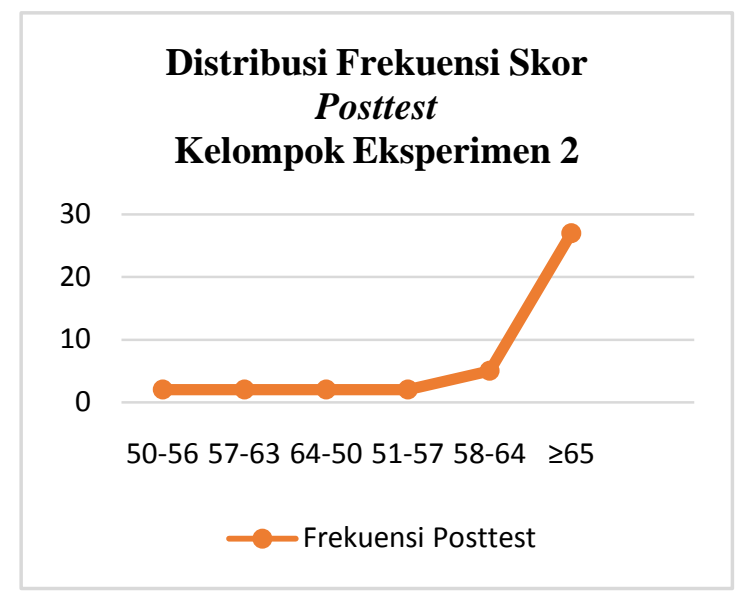

\section{Gambar 4.}

Grafik Distribusi Frekuensi Skor Posttest Kelompok Kontrol Menggunakan Model Discovery Learning

Hasil pengukuran dari kelompok eksperimen 1 dan kelompok eksperimen 2 berdasarkan nilai Pretest dan Posttest akan dijelaskan pada deskripsi komparasi ini. Deskripsi tersebut disajikan dalam bentuk tabel dan grafik seperti berikut:

Tabel 6. Komparasi Hasil Pengukuran Pretest dan Posttest Kelompok Eksperimen 1 dan Kelompok Eksperimen 2

\begin{tabular}{|c|c|c|c|}
\hline \multirow{2}{*}{$\begin{array}{c}\text { Tahap } \\
\text { Pengukuran }\end{array}$} & \multicolumn{2}{|c|}{ Rerata Skor (mean) Kelompok } & \multirow{2}{*}{$\begin{array}{c}\text { Keterangan } \\
\text { Selisih }\end{array}$} \\
\hline & Eksperimen 1 & Eksperimen 2 & \\
\hline Pretest & 49,02 & 49,83 & 0,81 \\
\hline Posttest & 73,3415 & 71,7561 & 1,5854 \\
\hline
\end{tabular}


Berdasarkan tabel 6 di atas maka dapat dilihat nilai rata-rata kelas eksperimen 1 pada tahap awal (pretest) adalah 49,02 dan nilai akhir (posttest) 73.3415. Sedangkan pada kelompok eksperimen 2 diperoleh nilai ratarata 49,83 pada tahap awal (pretest) dan 71,7561 pada tahap akhir (posttest).
Selanjutnya untuk selisih nilai rata-rata tahap awal (pretest) kelompok eksperimen 1 dan kelompok eksperiman 2 sebesar 0,81 sedangkan pada tahap akhir (posttest) sebesar 1,5854. Secara ringkas deskripsi komprasi hasil pengukuran tersebut dapat dilihat pada gambar 5.

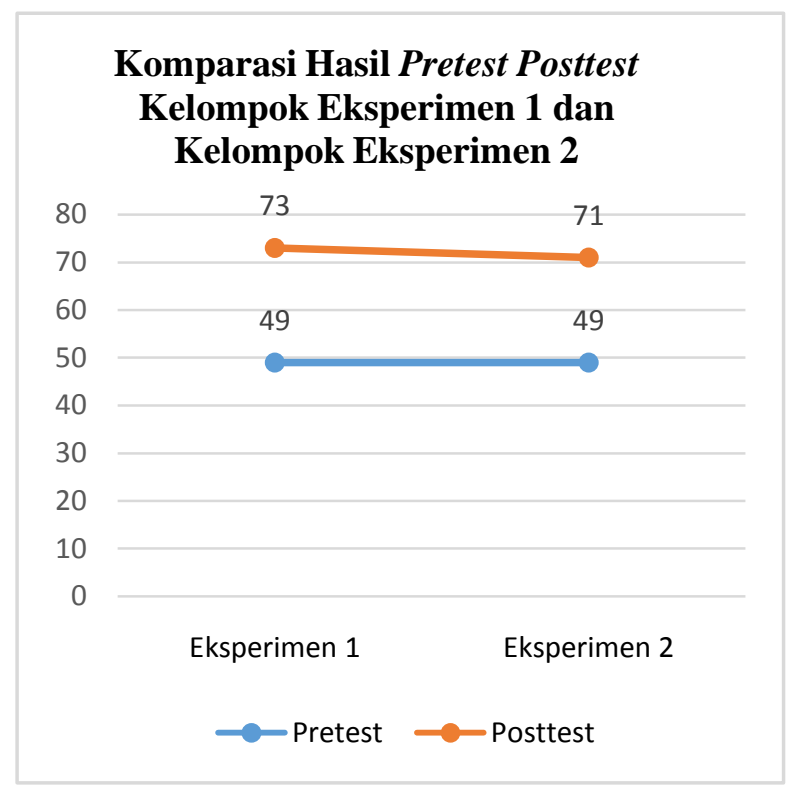

Gambar 5.

Deskripsi Komparasi Skor Pretest dan Posttest Kelompok Eksperimen 1 dan Ekperimen 2

Setelah dilakukan komparasi hasil pengukuran data tersebut langkah selanjutnya adalah melakukan uji normalitas yang menunjukkan data berdistribusi normal, dan uji homogenitas yang menunjukkan varian data homogen, dan uji homogenitas regresi linier maka dapat dikatakan uji prasyarat telah terpenuhi. Uji analisis berikutnya adalah ANCOVA atau uji kombinasi analisis regresi dan varians yang dapat dilihat dalam tabel 7 berikut: 
Tabel 7.

Ringkasan Hasil Uji ANCOVA

Tests of Between-Subjects Effects

\begin{tabular}{|c|c|c|c|c|c|c|}
\hline Source & $\begin{array}{l}\text { Type III } \\
\text { Sum of } \\
\text { Squares } \\
\text { df }\end{array}$ & $\begin{array}{l}\text { Mean } \\
\text { Square }\end{array}$ & $\begin{array}{l}\text { Mean } \\
\text { Square }\end{array}$ & $\mathrm{F}$ & Sig. & $\begin{array}{l}\text { Partial Eta } \\
\text { Squared }\end{array}$ \\
\hline Corrected Model & $\begin{array}{r}5527.188 \\
\mathrm{a}\end{array}$ & 2 & 2763.594 & 36.348 & .000 & .482 \\
\hline Intercept & 7469.163 & 1 & 7469.163 & 98.239 & .000 & .557 \\
\hline Pretest & 5505.227 & 1 & 5505.227 & 72.408 & .000 & .481 \\
\hline $\begin{array}{l}\text { Model } \\
\text { Pembelajaran }\end{array}$ & 50.334 & 1 & 50.334 & .662 & .418 & .008 \\
\hline Error & 5930.392 & 78 & 76.031 & & & \\
\hline Total & $\begin{array}{l}441065.0 \\
00\end{array}$ & 81 & & & & \\
\hline Corrected Total & $\begin{array}{l}11457.58 \\
0\end{array}$ & 80 & & & & \\
\hline
\end{tabular}

a. R Squared $=.482($ Adjusted R Squared $=.469)$

Ringkasan uji ANCOVA pada tabel 4.10 tersebut menunjukkan bahwa besarnya nilai $\mathrm{F}$ dan signifikansinya.Pada sumber varian corrected model, nampak bahwa $\mathrm{F}$ hitung sebesar 36,348 dengan taraf siginifikansi hitung 0,000 . Oleh karena $0,000<\alpha=0,050$, maka dampak variabel independen secara simultan terhadap variabel dependen signifikan. Artinya model pembelajaran Discovery Learning dan pretest secara simultan memiliki dampak yang berbeda secara signifikan terhadap hasil belajar siswa, dibandingkan dengan model pembelajaran Problem Solving.

\section{Pembahasan}

Berdasarkan uji ANCOVA yang telah dilakukan terhadap nilai Posttest kelompok eksperimen 1 dan kelompok eksperimen 2 diperolehhasil signifikansi/probabilitas 0,000 atau $<0,05$ maka $\mathrm{H}_{0}$ ditolak dan $\mathrm{H}_{\mathrm{a}}$ diterima. Artinya hasil belajar menggunakan model Discovery Learning lebih unggul secara signifikan disbanding model Problem Solving pada pembelajaran Tematik kelas IV SD Gugus Merbabu dalam pembelajaran menggunakan model pembelajaran Discovery Learning dan Problem Solving.

Sejalan dengan penelitian yang telah dilakukan, Mawardi dan Mariati (2016: 127142) dengan judul penelitian Kmparasi Model Pembelajaran Discovery Learning dan Problem Solving ditinjau dari hasil belajar IPA Siswa kelas 3 SD digugus DiponegoroTengaran, Hasil uji t skor postes menunjukkan $\mathrm{t}$ hitung 3,417 dan $\mathrm{t}$ tabel 2,021 dengan signifikansi 0,001 serta $t$ hitung gain score sebesar 2,129 dan $t$ tabel 2,021 dengan signifikansi 0,039. Karena nilai signifikansi < 0,05 dan $\mathrm{t}$ hitung $<\mathrm{t}$ tabel maka $\mathrm{H}_{\mathrm{O}}$ ditolak, $\mathrm{H}_{\mathrm{a}}$ diterima, artinya ada perbedaan hasil belajar yang signifikan dalam penerapan model pembelajaran Discovery Learning pada siswa kelas 3 SD di gugus Diponegoro Tengaran.

Wahyudi \& Mia Christy Siswanti (2015: 23) yang meneliti mengenai pengaruh model Discovery Learning dengan permainan 
ditinjau dari hasil belajar matematika siswa kelas 5. Kelas eksperimen dalam penelitian diterapkan model discovery learning sedangkan kelas kontrol diterapkan model konvensional. Berdasarkan analisis data yang telah dilakukan diperoleh hasil bahwa rata-rata kelas eksperimen 80,84 sedangkan kelas kontrol 71,75. Bukti selanjutnya didapatkan dari perhitungan uji $\mathrm{t}$ yang memperoleh nilai signifikasi yaitu $0,00<0,05$ yang berarti bahwa Ho ditolak dan Ha diterima. Sehingga dalam hal ini penggunaan model discovery learning dengan permainan dapat meningkatkan hasil belajar siswa kelas 5 Semester II SD Kristen 3 Eben Haezer. Walaupun jenjang kelas yang diteliti berbeda, namun jenis penelitian, mata pelajaran yang diteliti serta hasil penelitian yang ditemukan sama, yaitu diterapkanya model discovery learning dalam pembelajaran dapat meningkatkan hasil belajar siswa dalam mata pelajaran matematika.

Temuan Ira Vahlia dan Rina Agustina (2016: 82-93), bahwa pada kelas ekperimen I yang menerapkan model pembelajaran grub investigation berbasis problem solving diperoleh nilai rata-rata hasil belajar sebesar 73,10 sedang pada kelas eksperimen II yang menerapkan discovery learning berbasis peoblem solving diperoleh nilai rata-rata posttest sebesar 66,55. Terdapat perbedaan yang signifikan antara hasil belajar siswa pada kelas yang menerapkan discovery learning berbasis problem solving dan kelas yang menerapkan model pembelajaran groub investigation berbasis problem solving pada pokok bahasan numerik. Hasil belajar mahasiswa pada pembelajaran groun investigation berbasis problem solving lebih baik pada kelas yang menerapkan model pembelajaran discovery learning berbasis problem solving.

\section{SIMPULAN DAN SARAN}

Berdasarkan analisis data dan hasil penelitian yang telah dibahas pada bab sebelumnya, maka dapat disimpulkan bahwa hasil belajar dengan menggunakan model pembelajaran Discovery Learning lebih tinggi secara signifikan dibandingkan model pembelajaran Problem Solvingpada pelajaran Tematik kelas IV SD Gugus Merbabu. Hasil uji hipotesis menggunakan teknik ANCOVA seperti yang telah dilakukan terhadap nilai pretest dan posttest kelompok eksperimen 1 dan kelompok eksperimen 2 diperoleh hasil signifikansi/probabilitas 0,000 pada taraf kesalahan 5\% (0,05) sebesar $0,000<$ 0,05.Karena angka probabilitas menunjukkan lebih kecil dari nilai Alpha, maka dari itu $\mathrm{H}_{0}$ ditolak dan $\mathrm{H}_{\mathrm{a}}$ diterima. Maknanya hasil belajar Tematik siswa dengan menggunakan model pembelajaran Discovery Learning lebih tinggi secara signifikan dibandingkan dengan model pembelajaran Problem Solving pada siswa kelas IV SD Gugus Merbabu.

Dari hasil penelitian yang diperoleh, maka peneliti menyarankan sebagai berikut: 1) Model pembelajaran Discovery Learning dan Problem Solving digunakan dalam kegiatan pembelajaran, karena kedua model mempunyai kemampuan yang sama untuk diterapkan. 2) Adanya penelitian dapat digunakan sebagai referensi untuk mengembangkan penelitian selanjutnya, namun yang terdapat namun dengan memperhatikan keterbatasan yang terdapat dalam penelitian ini. Sehingga diharapkan untuk kedepannya penelitian yang dilakukan dapat lebih baik.

\section{DAFTAR PUSTAKA}

Agus, Suprijono, 2009. Cooperative Learning Teori dan Aplikasi PAIKEM. Yogyakarta.Pustaka Belajar.

Departemen Pendidikan Nasional, (2006). Kurikulum Tingkat Satuan Pendidikan Untuk Sekolah Dasar. Depdikbud. Jakarta.

Djamarah, S. B., \& Zein, Aswan. (1010). Strategi belajar mengajar. Jakarta: PT Asdi Mahasatya.

I Made Putrayasa, H. Syahruddin, I Gede Margunayasa. 2014. Pengaruh Model Pembelajaran Discovery Learning dan Minat Belajar Terhadap Hasil Belajar IPA Siswa. Jurnal Mimbar PGSD Universitas Ganesha. 2(1), 121-137

Ina Azariya Yupita, Waspodo Tjipto S. 2013. Penerapan Model Pembelajaran Discovery Learning untuk Meningkatkan Hasil Belajar IPS di Sekolah Dasar. JPGSD. 1(2): 0-216 
Kemendikbud. 2014. Materi Pelatihan Guru Implementasi Kurikulum 2013. Pusat Pengembangan Profesi Pendidik Badan Pengembangan Sumber Daya Manusia Pendidikan dan Kebudayaan dan Penjamin Mutu Pendidikan: Jakarta.

Mawardi \& Desty Lusia Sari. 2015. Keefektifan Model Pembelajaran Picture and Picture dan Make A Match Ditinjau dari Hasil Belajar dalam Pembelajaran IPA Kelas 4 SD Gugus Mawar-Suruh. Scholaria. 5 (3), 82-99.

Mawardi \& Rismaerista Rini. 2015. Peningkatan Keterampilan Proses Saintifik dan Hasil Belajar Siswa Kelas 4 SDN Slungkep 02 Tema Peduli Terhadap Makhluk Hidup dengan Menggunakan Model Problem Based Learning. Scholaria. 5 (1), 103-113.

Mawardi, M., \& Mariati, M. (2016). Komparasi Model Pembelajaran Discovery Learning dan Problem Solving Ditinjau Dari Hasil Belajar Ipa Pada Siswa Kelas 3 SD Di Gugus Diponegoro-Tengaran. Scholaria: Jurnal Pendidikan dan Kebudayaan, 6(1), 127-142

Meiria Sylvi Astuti. 2015. Peningkatan Keterampilan Bertanya dan Hasil
Belajar Siswa Kelas 2 SDN Slungkep 03 Menggunakan Model Discovery Learning.Scholaria. 5(1), 10-23

Pepkin, K.L. 2004. http://www.mathematic.Transdigit.com/ mathematic-article/creative-problem$\underline{\text { solving-in-math.html }}$

Rusman. (2011). Model-Model Pembelajaran: Mengembangkan Profesionalisme Guru, Jakarta: RajaGrafindo Persada.

Sugiyono. 2015. Metode Penelitian Pendidikan Pendekatan Kuantitatif, Kualitatifdan R\&D. Bandung: Alfabeta.

Sumber Daya Manusia Pendidikan dan Kebudayaan dan Penjamin Mutu Pendidikan: Jakarta.

Trianto. (2011). Desain Pengembangan Pembelajaran Tematik: Bagi Anak Usia Dini TK/RA danAnak Usia Kelas Awal $S D / M I$, Jakarta: Kencana

Wahyudi, W., \& Siswanti, M. C. (2015). Pengaruh Pendekatan Saintifik Melalui Model Discovery Learning dengan Permainan Terhadap Hasil Belajar Matematika Siswa Kelas 5 SD. Scholaria: Jurnal Pendidikan dan Kebudayaan, 5(3), 23-36. 